Arab Univ. J. Agric. Sci., Ain Shams Univ., Cairo, 14(1), 105-119, 2006

\title{
STUDIES ON BACTERIAL POLLUTION IN LAKE MANZALA
}

[7]

\author{
Mansour $^{1}$, F.A.; A. Ismail ${ }^{2 *}$; M.I. Abou-Dobara ${ }^{3}$ and M.M. Zaky
}

\begin{abstract}
Lake Manzala in Egypt have shown great changes in water properties including $\mathrm{pH}$ (7.4 to 8.4 ), total suspended solids ( 19 to $350 \mathrm{mg} / \mathrm{l}$ ), total dissolved salts (1578 to $33480 \mathrm{mg} / \mathrm{l})$, dissolved oxygen $(2.25$ to $8.45 \mathrm{mg} / \mathrm{l})$, ammonia $(0.00$ to $44.8 \mathrm{mg} / \mathrm{l})$ and nitrate $(0.00$ to $8.96 \mathrm{mg} / \mathrm{l})$. In addition there has been quite high bacterial density in water and fish of the lake, including total viable bacterial counts and indicator organisms such as total coliforms, faecal coliforms and some other organisms such as Aeromonas spp., Vibrio spp. and Staphylococcus spp. However, the magnitude number of bacteria in water and fish was found to vary sometimes considerably and sometimes slightly depending on the site of sampling. Our results herein showed that Lake Manzala is highly contaminated.
\end{abstract}

Keywords: Bacterial pollution, Lake Manzala

\section{INTRODUCTION}

Lake Manzala - the most important and largest brackish water in Egypt - is in the east of the Nile Delta between Damietta branch of the River Nile and Suez Canal. Lake Manzala suffers from pollution induced by agricultural drainage, industrial wastes and sewage, which makes the lake highly polluted and eutrified. The distribution of four indicators; faecal coliforms, Escherichia coli, Enter- ococci and Clostridium perfringens in six waste water resources in lake Manzala has been studied by El-Sarangawy (1990) and he found that maximal bacterial numbers were detected during the summer seasons and at Bahr El-Bakar area and El-Gamil outlet and much lower bacterial numbers were noted in winter time. The contamination of Lake Manzala can cause the spread of many infectious diseases, such as typhoid, dysentery and gastroenteritis.

1- Botany Department, Faculty of Science, Mansoura University, Mansoura, Egypt.

2- Biological Sciences Department, Faculty of Education, Suez Canal University, Port Said, Egypt.

3- Botany Department, Faculty of Science, Mansoura University, Damietta, Egypt.

*Correspondence: Ahmey@myway.com

(Received December 10, 2005)

(Accepted December 27, 2005) 
In this paper the aim of our study was to determine the influence of pollution on the physiochemical and bacterial properties of the water of Lake Manzala.

\section{MATERIAL AND METHODS}

\section{Sampling localities}

Samples localities were selected close and around Lake Manzala and that affect the lake condition and human health, namely El-Kapoty, El-Gamil, El-Bashtier and El-Mataryia areas.

\section{Sampling method}

Sampling was carried out seasonally throughout one-year period and water samples were collected in clean sterile glass bottles and transported from the lake to the laboratory in ice bags and ice jackets for direct examination. Physical parameters such as temperature and $\mathrm{pH}$ were determined directly in the field and the other physical, chemical and bacteriological analyses were done in the laboratory.

\section{Physical and chemical parameters of water samples}

Total suspended solids (TSS) and total dissolved salts (TDS) were determined according to the methods of American Public Health Association, APHA (1995). Salinity and dissolved oxygen (DO) were determined using the refractometer (Atago S/Mill, model 8607) and oxygen meter (Eilprobe, model 8012) respectively. Ammonia and the nitrate were determined using the methods of APHA (1995).

\section{Bacterial counts of water}

Water samples were directly diluted with $0.8 \%$ saline distilled water for bacterial counting using the dilution method and pour plate method (APHA 1995). Total viable bacteria were determined using nutrient agar medium while total coliforms and faecal coliforms were determined using Endo agar medium (APHA 1995). Aeromonas spp. were determined using Aeromonas differential agar medium while Vibrio spp. were determined using thiosulphate citrate bile salts sucrose agar medium. Finally, salt mannitol agar was used for counting Staphylococcus spp. All media used were according to Cheesbrough (1985).

The operculate surface of the fish body was scrubbed thoroughly with povidone-iodine solution requited to contain $1 \%$ iodine. The operculate were then removed to expose the gill tissues. Aseptic procedures were used when the gill lamellae were cut and weighed in sterile dishes (Trust 1975). The fish was dissected and $1.0 \mathrm{~g}$ of the intestinal contents was aseptically stripped out with sterile forceps. Samples of gill lamellae and intestinal contents $(1.0 \mathrm{~g})$ were aseptically resuspended in $100 \mathrm{ml}$ of $0.1 \%$ (w/v) chilled peptone water $(\mathrm{pH} 7.0)$ and homogenized at $20 \mathrm{rpm}$ (Homogenizer Model VIRTIS, USA) for 6 times, each of 30 seconds using motor with cooling in an ice bath to avoid overheating.

\section{Statistical analysis}

Correlation analysis (Fowler and Cohen 1996) was used to test the significance of relationships between the bacterial count and water characteristics of 
Lake Manzala. The correlation coefficient $(\mathrm{r})$ and the probability $(\mathrm{P})$ were used.

\section{RESULTS}

\section{Physical and chemical parameters of Lake Manzala Water}

The results presented in Figure (1a) indicate that there was no great difference between the studied sites in water temperatures during the same season and the temperature ranges, in general, between $13^{\circ} \mathrm{C}$ in winter and $31^{\circ} \mathrm{C}$ in summer. There was insignificance difference between temperature in all sites of Lake Manzala.

Most the investigated sites are alkaline (Fig.1b) and there was no seasonal variation in the $\mathrm{pH}$ values (7.4 to 8.4 ). In the different sites of Lake Manzala there was insignificant difference between $\mathrm{pH}$.

The salinity levels in El-Kapoty and El-Gamil areas were greater than that of El-Bashtier and El-Mataryia (Fig. 1c). Highest salinity was recorded in summer at El-Kapoty site where it reached 29 $\mathrm{mg} / \mathrm{l}$; while the lowest value $(3.5 \mathrm{mg} / \mathrm{l})$ was recorded in winter at El-Mataryia.

The dissolved oxygen exhibits great seasonal variation among the studies sites (Fig. 1d). The lowest value $(2.25 \mathrm{mg} / \mathrm{l})$ was recorded in water of El-Kapoty area in winter while the highest value $(8.45$ $\mathrm{mg} / \mathrm{l}$ ) was recorded in water samples collected from El-Mataryia in winter.

The total suspended solids appeared to vary greatly during the different seasons at various sites where it ranged form $19 \mathrm{mg} / \mathrm{l}$ in autumn at El-Bashtier to 350 $\mathrm{mg} / \mathrm{l}$ in winter at El-Gamil outlet (Fig. 2a). The dissolved salts varied seasonally; the lowest value $(1578 \mathrm{mg} / \mathrm{l})$ was record- ed in autumn at El-Mataryia area and the highest value $(33480 \mathrm{mg} / \mathrm{l})$ was recorded in winter at El-Gamil outlet (Fig. 2b). The salinity in all the investigated sites of Lake Manzala was highly significant different $(\mathrm{P}<0.01)$.

There was a difference in ammonia level of water among the different localities (Fig. 2c). In autumn at El-Gamil outlet and in summer at El-Mataryia there was no ammonia recorded and the highest value $(44.8 \mathrm{mg} / \mathrm{l})$ was recorded in autumn at El-Bashtier area.

The amount of nitrate varied considerably among the different sites investigated (Fig. 2d). The highest value (8.96 $\mathrm{mg} / \mathrm{l})$ was recorded in water sample collected form El-Kapoty in winter.

\section{Bacterial counts of water}

There is a seasonal variation in the total viable bacterial density in all the investigated areas where the lowest record $\left(10^{2} \mathrm{cfu} / \mathrm{ml}\right)$ was at El-Gamil outlet in summer and the highest record $\left(10^{4}\right.$ $\mathrm{cfu} / \mathrm{ml}$ ) was in El-Kapoty at summer (Fig. 3a). The total viable bacterial count was significantly correlated with temperature, salinity, total suspended solids, total dissolved salts, ammonia and nitrate $(\mathrm{r}=$ $0.92,0.98,0.94,0.97,0.68$ and $0.87 ; \mathrm{P}$ $<0.05)$ respectively.

The number of the total coliforms increases from autumn, winter, spring to summer in most of the studied sites (Fig. 3b.). The total coliforms was significantly correlated with salinity, total suspended solids, total dissolved salts and temperature $(\mathrm{r}=0.88,0.74,0.78$ and $0.87 ; \mathrm{P}$ $<0.05)$ respectively. In El-Gamil outlet, the total coliforms and dissolved oxygen were correlated $(\mathrm{r}=-0.90 ; \mathrm{P}<0.05)$. 


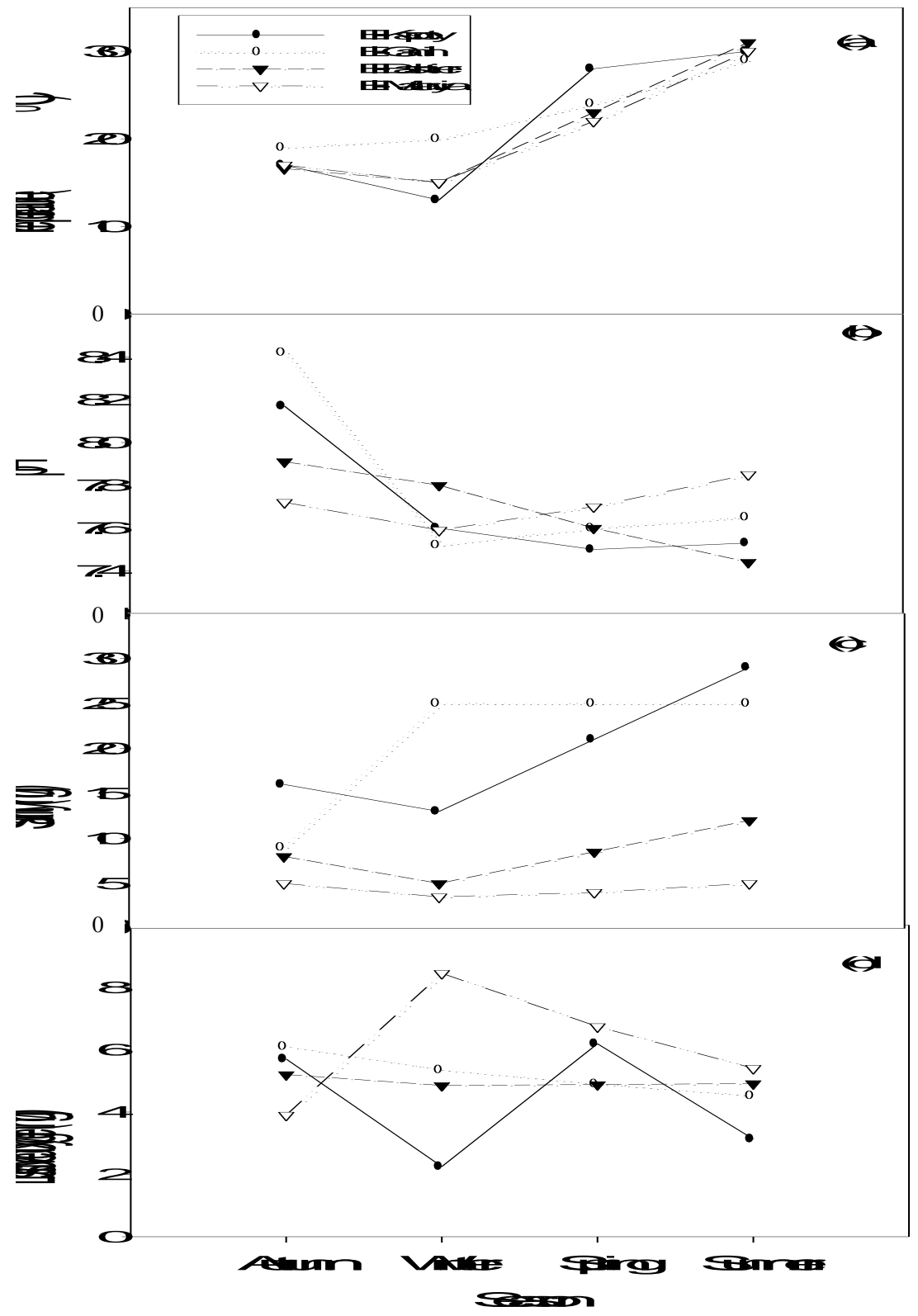

Fig. 1. The temperature (a), pH (b), salinity (c) and dissolved oxygen (d) of the different areas of Lake Manzala, seasonally along one year 


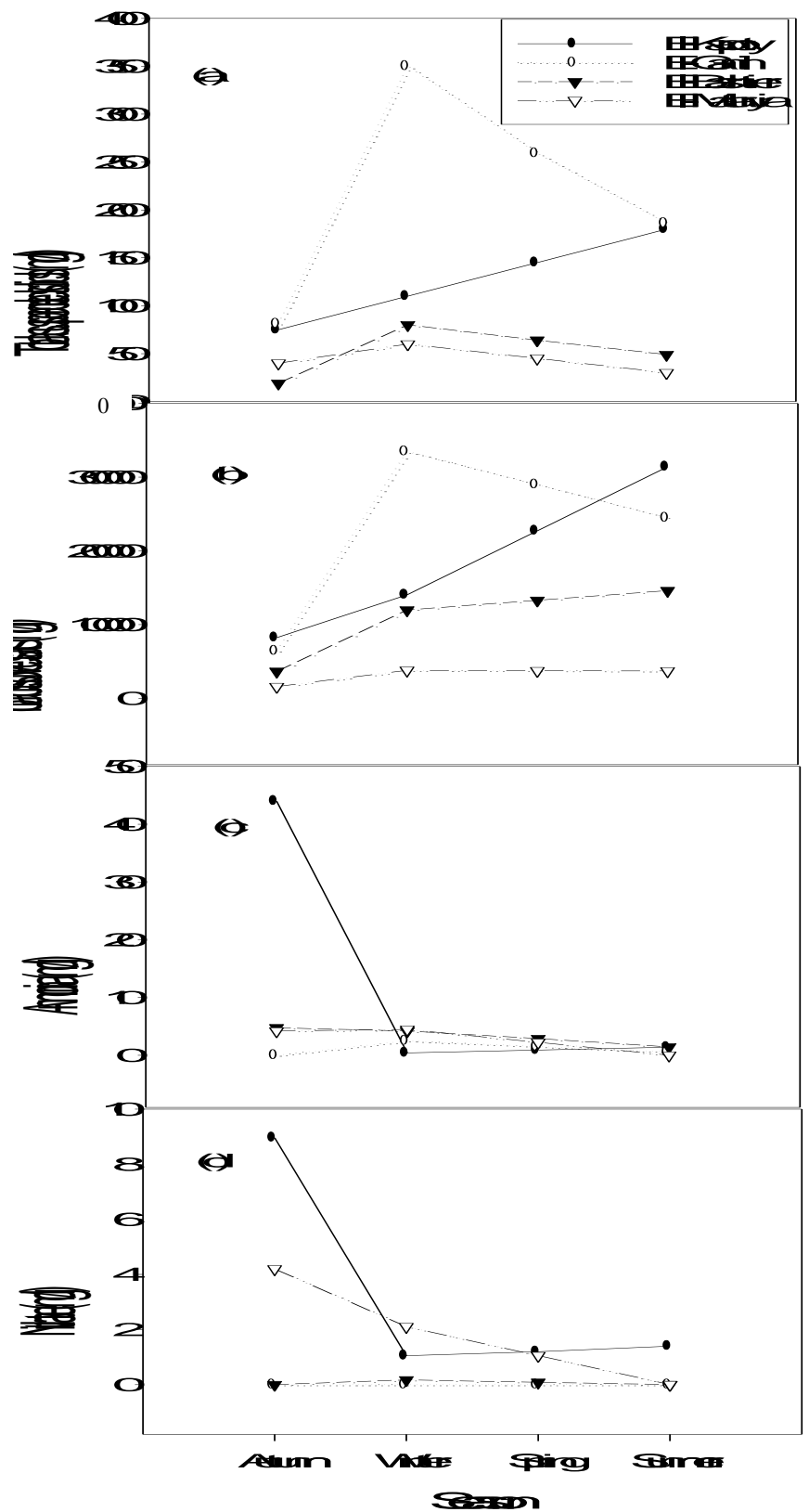

Fig. 2. Total suspended solids (a), total dissolved salts (b), ammonia (c) and nitrate (d) of the different areas of Lake Manzala, seasonally along one year 
The faecal coliforms varied greatly in the different seasons and there is seasonal increase in the number of the faecal coliforms to reach the highest count $\left(38 \times 10^{2}\right.$ $\mathrm{cfu} / \mathrm{ml}$ ) at El-Kapoty in summer (Fig. 3c). The faecal coliforms was significantly correlated with temperature, salinity, total suspended solids and nitrate $(r=0.87$, $0.98,0.91$ and $0.84 ; \mathrm{P}<0.05)$ respectively. In El-Mataryia area, the faecal coliform and total dissolved salts were correlated $(\mathrm{r}=-0.96 ; \mathrm{P}<0.05)$.

The number of the Aeromonas spp. was generally higher in autumn than the other seasons in all the studied areas (Fig. 4a). Aeromonas spp. and $\mathrm{pH}$, ammonia, nitrate and dissolved oxygen were significantly correlated $(r=0.89,0.93,0.93$ and 0.99; $\mathrm{P}<0.05)$ respectively. On the other hand, Aeromonas spp. and salinity and total dissolved salts were correlated ( $\mathrm{r}=-$ 0.99 and $-0.95 ; \mathrm{P}<0.05)$ respectively in El-Gamil outlet.

The count of the Vibrio spp. varied in the studied areas and the highest count (5 $\left.\mathrm{X} 10^{2} \mathrm{cfu} / \mathrm{ml}\right)$ was at El-Kapoty area in spring (Fig. 4b). Vibrio spp. was strongly correlated with total suspended solids, total dissolved salts and ammonia $(\mathrm{r}=0.96,0.90$ and $0.95 ; \mathrm{P}<0.05)$ respectively, while in El-Kapoty area Vibrio spp. was moderately correlated with temperature and dissolved oxygen $(r=0.55$ and $0.60 ; \mathrm{P}<0.05)$ respectively.

There is a remarkable seasonal variation of the number of Staphylococcus spp. in all sites where the lowest record (50 $\mathrm{cfu} / \mathrm{ml})$ at El-Bashtier in autumn and the highest number $\left(21 \times 10^{2} \mathrm{cfu} / \mathrm{ml}\right)$ at ElKapoty site in summer (Fig.4c). Staphylococcus spp. was strongly correlated with temperature, salinity, total suspended solids, total dissolved salts and $\mathrm{pH}$ $(\mathrm{r}=0.90,0.97,0.95,0.98$ and $0.88 ; \mathrm{P}$ $<0.05)$ respectively.

\section{Bacterial counts in fish samples}

The total viable bacterial counts varied seasonally in fish taken from two sites - namely - El-Bashtier and El-Mataryia areas. The number was very high in the whole fish $\left(48 \times 10^{5} \mathrm{cfu} / \mathrm{g}\right)$ collected from El-Mataryia site in summer, but the flesh of the fish appeared to harbor much lower number $(100 \mathrm{cfu} / \mathrm{g})$ at the two sites in summer (Fig.5a). In El-Mataryia area, the total viable bacterial count in the whole fish was significantly correlated with intestine $(\mathrm{r}=0.98 ; \mathrm{P}<0.05)$.

Number of total coliform bacteria varied considerably between the different parts of the fish taken from the two sites. As could be deducted from the Fig.5b, the highest number $\left(5 \times 10^{6} \mathrm{cfu} / \mathrm{g}\right)$ had been recorded in the whole fish in El-Mataryia in spring while the smallest number (100 $\mathrm{cfu} / \mathrm{g}$ ) had been reported in the fishes collected from El-Bashtier area in summer. In El-Bashtier area, the total coliform on fish gills was strongly correlated in the flesh $(\mathrm{r}=0.95 ; \mathrm{P}<0.05)$.

There was a small number of faecal coliform bacteria $(60 \mathrm{cfu} / \mathrm{g})$ on the surface of the fish taken from El-Bashtier area in autumn while there was greater number on fish surface from the same area in summer (Fig.5c). The numbers of faecal coliform in the gills $(500 \mathrm{cfu} / \mathrm{g}$ ) and flesh of the fish $(100 \mathrm{cfu} / \mathrm{g})$ collected from El-Bashtier area in winter, spring and summer were more while the same number of faecal coliform in gills and flesh $(2000 \mathrm{cfu} / \mathrm{g})$ has been reported in fish collected from in El-Mataryia in winter. The faecal coliforms on the fish gills 


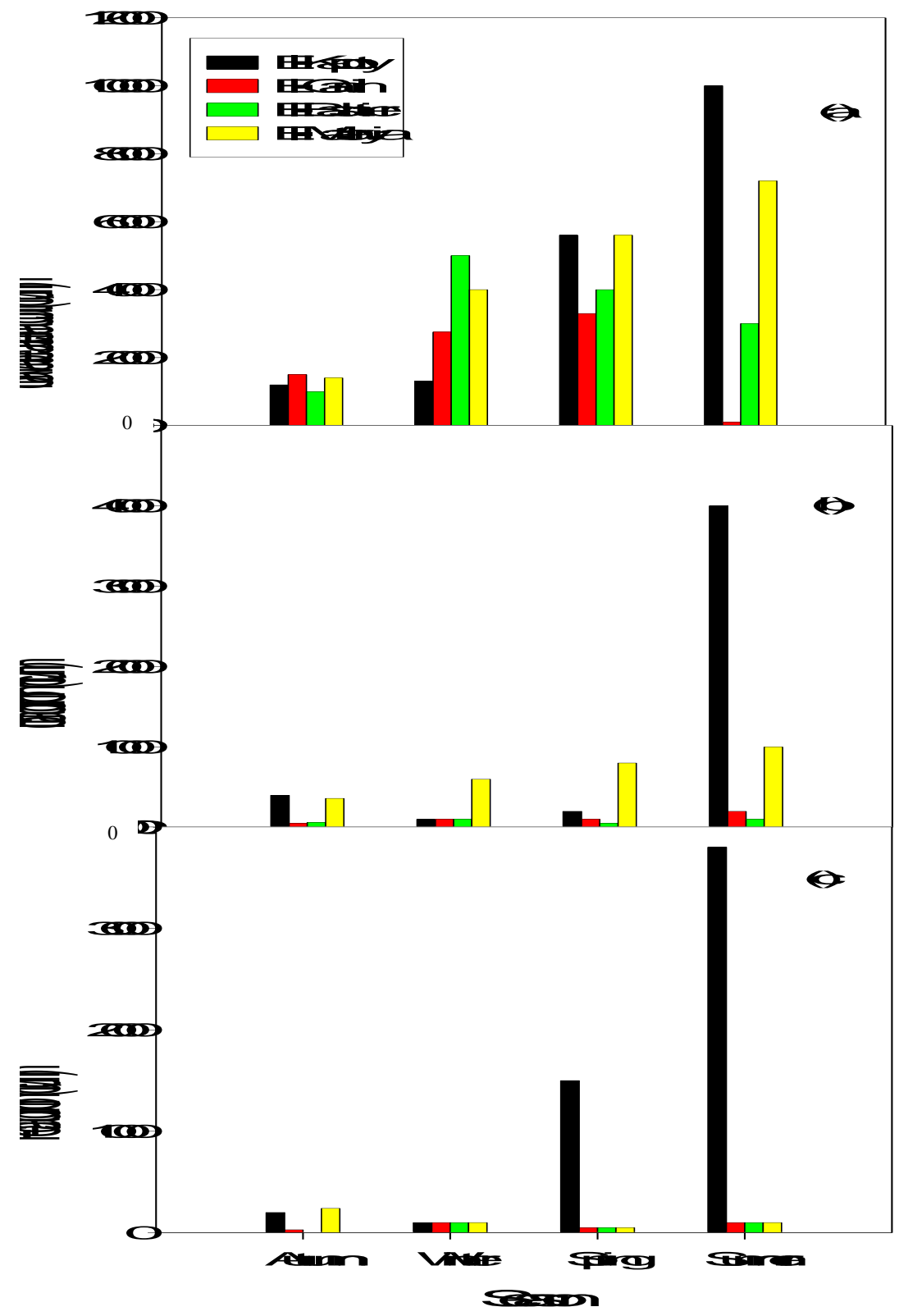

Fig. 3. Counts of total viable bacteria (a), total coliforms (b) and faecal coliforms (c) of the different areas of Lake Manzala, seasonally along one year. 


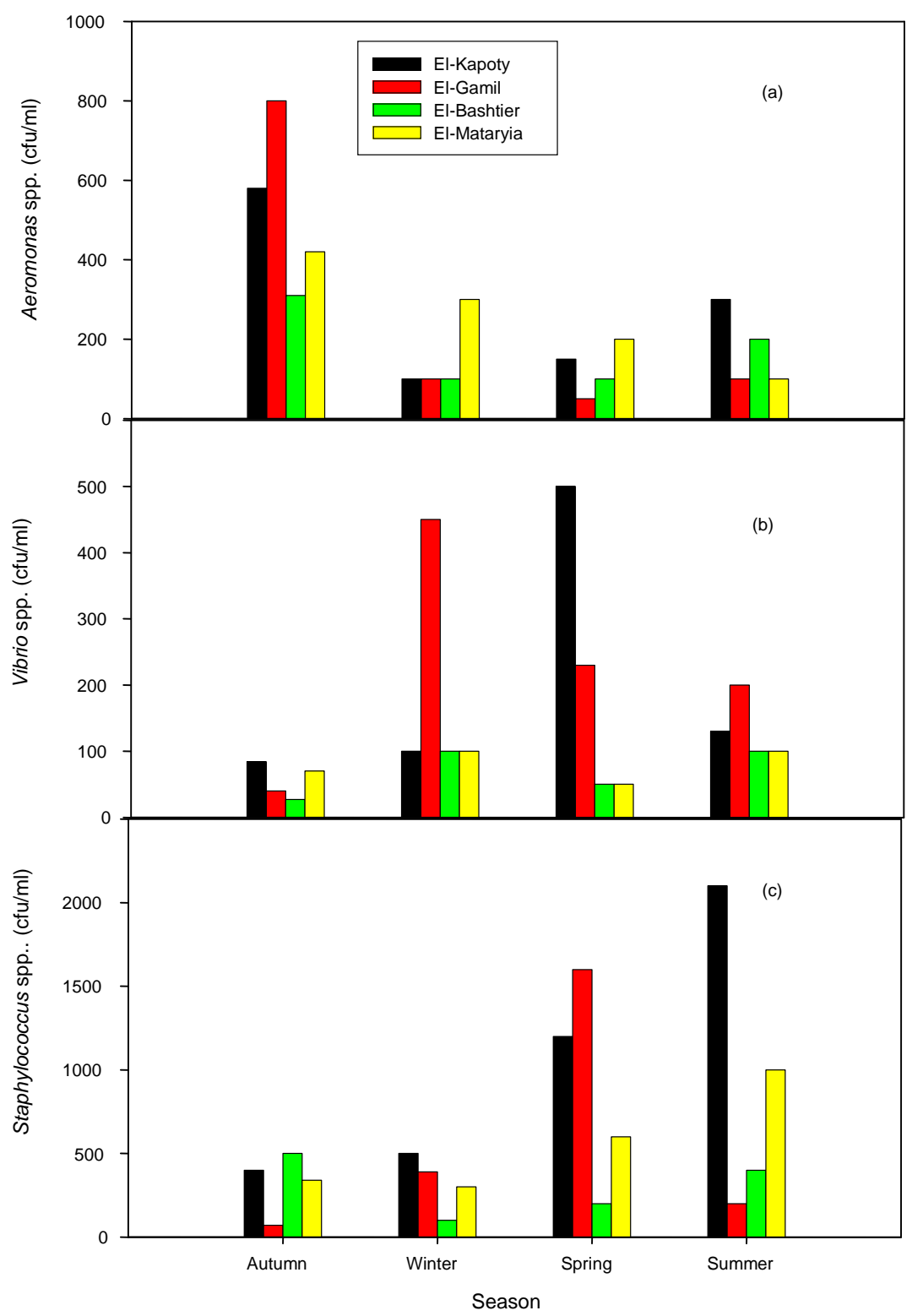

Fig. 4. Counts of Aeromonas spp. (a), Vibrio spp. (b) and Staphylococcus spp. (c) of the different areas of Lake Manzala, seasonally along one year. 


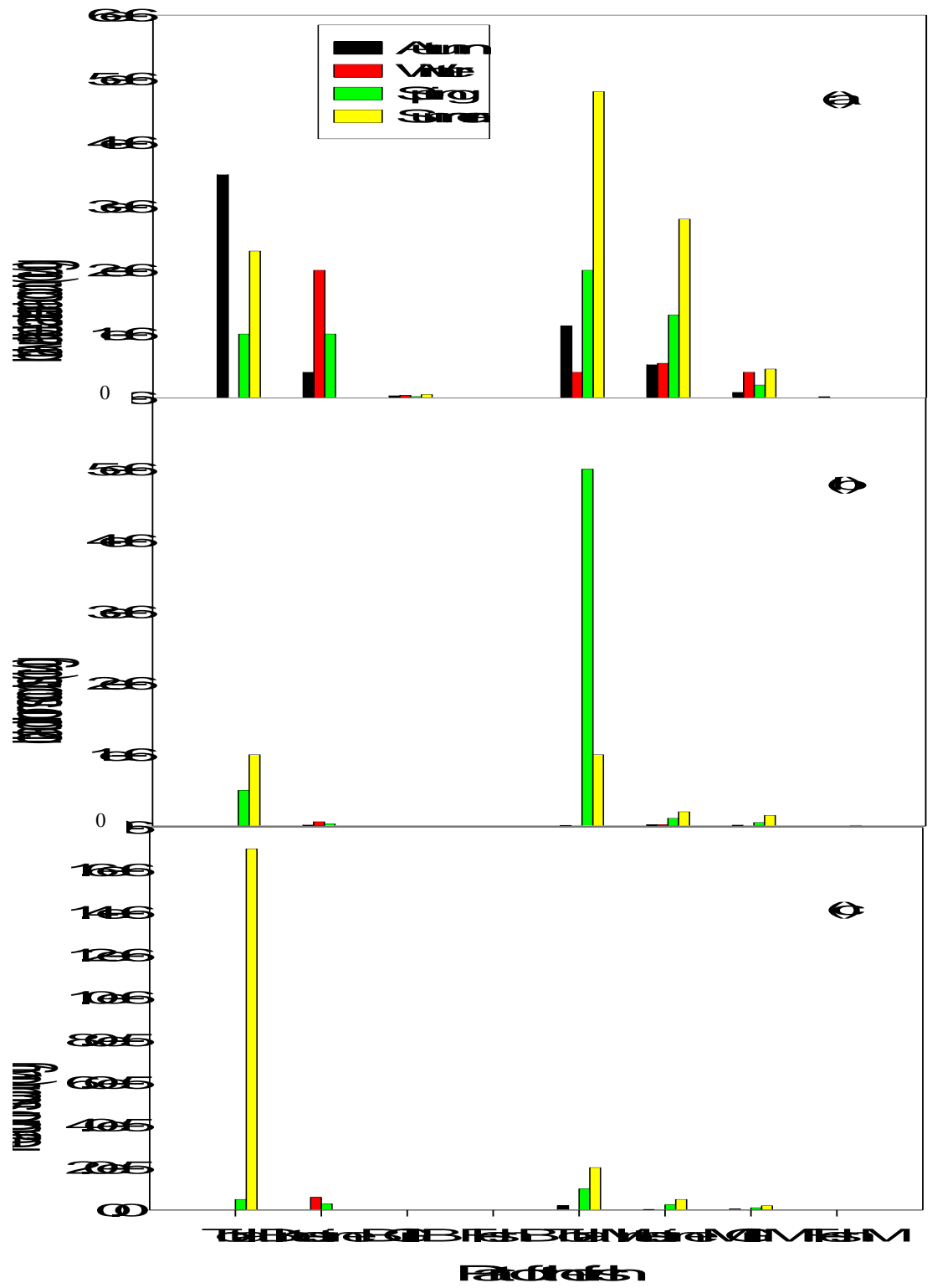

Fig.5. Counts of total viable bacteria (a), total coliforms (b) and faecal coliforms (c) of the fishes collected from El-Bashtier (B) and El-Mataryia (M) areas, seasonally along one year. 
was significantly correlated with flesh $(\mathrm{r}=0.86 ; \mathrm{P}<0.05)$ in El-Bashtier area while in El-Mataryia area there was a significant correlation between the faecal coliforms in the whole fish, intestine and gills $(r=0.87$, and $0.95 ; \mathrm{P}<0.05)$ respectively.

The total counts of Aeromonas spp. in fish taken from El-Bashtier area were always seasonally lower than that recorded in the fishes collected from ElMataryia area (Fig. 6a). The highest count of Aeromonas spp. $\left(14 \times 10^{5} \mathrm{cfu} / \mathrm{g}\right)$ was detected in the whole fish in autumn. In El-Mataryia area, Aeromonas spp. in the fish flesh and the intestine was strongly correlated $(\mathrm{r}=0.73 ; \mathrm{P}<0.05)$.

The number of Vibrio spp. varied in the fishes taken from the two sites - ElBashtier and El-Mataryia (Fig. 6b). The number was low $(100 \mathrm{cfu} / \mathrm{g})$ in fish collected from El-Bashtier area in the intestine and the flesh of the fish in summer and also the same number had been reported in the gills and the flesh the fish taken from El-Mataryia in the same season. On the other hand, the number of Vibrio spp. was very high $\left(2 \times 10^{6}\right.$ and $\left.4 X 10^{6} \mathrm{cfu} / \mathrm{g}\right)$ in the whole fish in ElBashtier area in spring and summer respectively. The count of Vibrio spp. in ElBashtier area in the whole fish and fish gills was significantly correlated $(\mathrm{r}=0.98$; $\mathrm{P}<0.05)$ while in El-Mataryia area Vibrio spp. in the intestine and gills was strongly correlated $(\mathrm{r}=0.99 ; \mathrm{P}<0.05)$.

The number of Staphylococcus spp. reported in fish collected from ElMataryia area was nearly lower than that recorded in fish taken from El-Bashtier site and the smallest number $(100 \mathrm{cfu} / \mathrm{g})$ was recorded in the gills and the flesh of the fish of El-Mataryia in summer (Fig. $6 c)$. Whereas the highest number $(800$ $\mathrm{cfu} / \mathrm{g}$ ) was detected in the gills of the fish of El-Bashtier and in the whole fish of ElMataryia in summer. Staphylococcus spp. count in El-Bashtier area in the fish gills and fish flesh was highly significant correlated ( $\mathrm{r}=0.99 ; \mathrm{P}<0.05)$. In El-Mataryia area, Staphylococcus spp. in the whole fish was strongly correlated with intestine $(\mathrm{r}=0.99 ; \mathrm{P}<0.05)$.

\section{DISCUSSION}

The present results indicate that temperature and $\mathrm{pH}$ values of the lake water were in normal range favorable for most bacteria to grow. This matches with other author (Khalil 1990) and this may be a plausible explanation for the presence of high number of total viable bacteria in water of Lake Manzala. High counts of the total viable bacteria of the lake water in summer months might be due to the increase of temperature that enhanced bacterial growth and multiplication.

The salinity values varied from one site to another, but generally the lake water is considered brackish because of its connections with the Mediterranean Sea. Awadhi and Khalil (1989) reported that the brackish water of the lake became less since 1920. This may be attributed to the large amounts of waste water which are disposed off into the lake from different drains, such as Bahr El-Bakar drain.

The concentration of oxygen in the aquatic environment has been reported to be an important effective factor in the decomposition and oxidation of organic nitrogenous constituents (Geldereich and Clark 1966). In the present study, the oxygen was low in all sites. The anoxic condition can explain the high readings of ammonia in the water of the lake, which consequently explains the eutrophic condition of the lake. Almost all the studied 


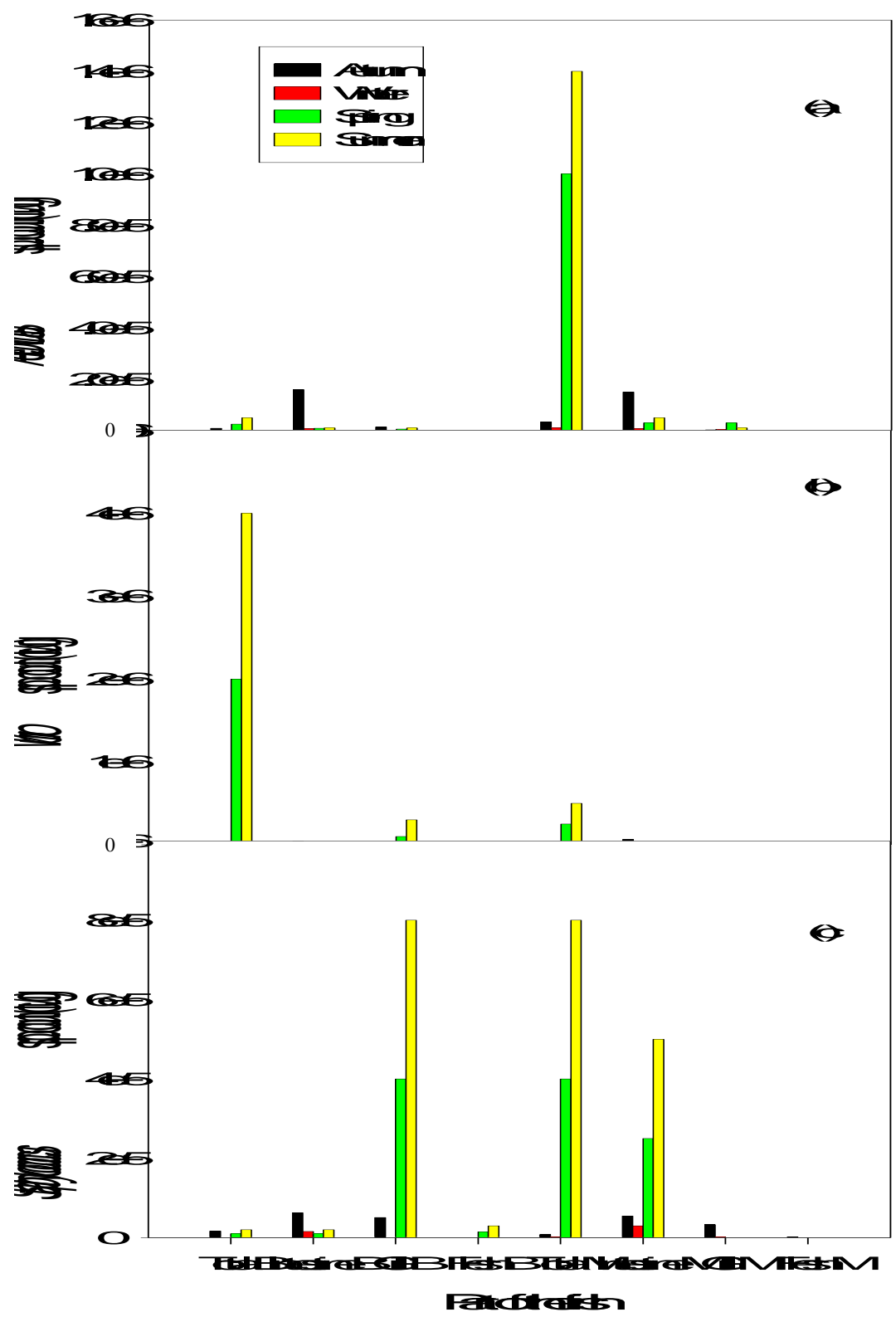

Fig. 6. Counts of Aeromonas spp. (a), Vibrio spp. (b) and Staphylococcus spp. (c) of the fishes collected from El-Bashtier (B) and El-Mataryia (M) areas, seasonally along one year. 
parameters indicated the polluted status beyond the limits of the legislation of the Law 48/1982.

El-Bashtier canal being a littoral zone and El-Mataryia area with rooted vegetation has the highest bacterial counts among the other studied areas of the lake. This interpretation has been also concluded (Quinn et al 1985).

The statistical analysis showed that there is a strong positive correlation between the total viable bacteria and the total suspended solids in the water of lake at the studied sites and this is in an agreement with a previous conclusion (Rhenheimer 1980).

Suspended particles whether of organic or mineral origin adsorb bacteria to their surfaces where the microbes find a more favorable nutritional environment than that in free water. In water with very low concentration of nutrients, most microorganisms have been shown growing on the surface of suspended particles. Moreover, inhibitory and toxic substances are neutralized by adsorption to particles of debris. Thus the suspended particles have favorable effect on the bacterial growth.

Total and faecal coliforms bacteria counts helped very much in dividing the lake according to its polluted conditions. With the reference to World Health Organization, WHO (1989) Standards, ElKapoty and El-Mataryia areas are considered as highly polluted sites in Manzala Lake. It seems that these groups of bacteria are still a powerful tool and the most trusted indicators of water pollution as they are routinely used by many researchers (Farrah and Bitton 1984; Simpson et al 2002). El-Mataryia area comes first being greatly polluted with numerous health hazardous bacterial counts, such as Vibrio spp., Aeromonas spp. and Staphylococcus according to World Health Organization, WHO (1989).

The statistical analysis showed that there is a strong positive correlation between total coliform, faecal coliform bacteria and certain pathogens such as Vibrio spp. and Staphylococcus spp. on one hand and salinity and total dissolved salts in water of the lake on the other in most sites. This could be an indication of salt tolerance of these bacteria due to the high load of waste which is disposed off into the lake water and the marine water and this could exert an adverse effect on these bacteria but along many years they could be genetically changed due to the mutations to adapt with the new stressed environment.

Also analysis revealed a positive correlation between Aeromonas spp. and ammonia level in lake water in some sites which indicate that Aeromonas spp. could flourish in the anoxic and polluted water; a phenomenon that suggest the use of Aeromonas as an indicator of pollution. In this connection it may be mentioned that Aeromonas spp. represented high percentage of isolates from water and fish of Lake Manzala (Zaky 1995). The positive correlation between counts of some pathogens such as Vibrio spp., Staphylococcus and coliforms (total or faecal coliforms) support the idea of suing these pathogens as pollution indicators together with coliforms bacteria.

Bacterial counts in the whole fish ( $\mathrm{Ti}$ lapia spp.) taken from El-Bashtier and ElMataryia areas have shown a similar pattern of total viable bacteria. Counts of the total viable bacteria in the intestine of the fish were higher than that in other fish parts. The enrichment media, temperature 
and other conditions such as the recent polluted intake gave good reasons for bacteria to flourish and increase in number. Although the microflora of gills in marine and fresh water fish appeared to differ quantitatively. The low bacterial numbers on the gills in general may be due to the production of mucous that acting as germ trap at the circulatory blood vessels enriched with antibodies and the lack of any nutritive materials.

The presence of faecal coliform bacteria and other pathogens indicated the polluted conditions of the water. The invasion of fish muscles by bacteria is very likely to occur in polluted water. So high incidence of bacterial counts in different fish parts can easily indicate the pollution levels of the water that they live in.

The statistical analysis showed strong positive correlation between the different bacterial counts of different pathogens in the gills, intestine and flesh of the fish taken from El-Bashtier and El-Mataryia areas. This indicates the origin of infection of the flesh from gills and intestine which could be a major anatomical part of the fish, which affect the number of bacteria in the flesh, and in the whole fish. This could be dangerous if it is eaten by people in the populations around the lake and this depends on the way that the people cock and eat the fish.

Not only the lake water but also fishes that have been found to have very high pathogenic bacteria. Some of these pathogens have dangerous extracellular products well known to be virulence linked factors and many of these pathogens exist in Lake Manzala. These organisms are related to different taxonomic groups especially family Enterobacteriaceae, Vibrionaceae, Staphylococcaceae and Pseudomonadaceae such as Escherichia coli, Salmonella spp., Shigella spp., Vibrio spp., Aeromonas spp., coagulase positive Staphylococcus aureus, Pseudomonas aeruginosa and Pseudomonas fluorescens (Zaky 1995; El-Gaber et al 1997; Soliman 1999; Wahaab and Badawy 2004). Yersinia spp. is actually enteric organisms, which is recorded in the water and fish of the River Nile (Hefnawi et al 1989) and also have been recoded in water and fish of lake Manzala (Ismail et al 2005). It could be waste water and sewage are the sources of Yersinia spp. where different species of Yersinia such as $Y$. enterocolitica, Y. fredreksenii, $Y$. intermedia and $Y$. krestesenii were isolated from waste water facilities (Ruhle et al 1990).

\section{REFERENCES}

American Public Health Association, APHA (1995). Standard Methods for Examination of Water and Waste Water, $19^{\text {th }}$ Ed. American Public Health Association, Washington,USA.

Awadhi, M.H.M. and M.T. Khalil (1989). Upgrading of physicochemical characteristics of lake Manzala. Egypt. Scientific Bulletin, Faculty of Engineering, Ain Shams University. 24(3): 1-20.

Cheesbrough, M. (1985). Medical Laboratory Manual for Tropical Countries. pp. 392-429. Bulterworth \& CO. publishers, LTD., London.

El-Gaber, G.A.; M. Naguib and E.S.A. El-Aziz (1997). Vibrio species infection in Oreochromis niloticus and Mugil cephalus: sodium chloride tolerance. Pathogenicity, serological relatedness and antibiograms sensitivity of recovered vibrios. Veterinary Medical J. Giza. 45(1): 87-99. 
El-Sarangawy, D.A. (1990). Pathogenic indicators of water in six wastewater resources in Lake Manzala, North Egypt, Part I, Bahr El-Bakar. Zagazig Veterinary J. 18(1): 26-34.

Farrah, S.R. and G. Bitton (1984). Enteric bacteria in aerobically digested study. Appl. Environ. Microbiol. 47(4): 831-834.

Fowler, J. and L. Cohen (1996). Practical Statistics for Field Biology. John Wiley and Sons, New York, USA.

Geldereich, E.E. and A.N. Clark (1966). Bacterial pollution indicators in the intestinal tract of fresh water fish. Appl. Environ. Microbiol. 14(3): 429. 437.

Hefnawi, Y.S.; S. Moustafa and R. Refaei (1989). Occurrence of Yersinia enterocolitica and Listeria monocytogenes. Assiut Veterinary Medical J. 21(41): 134-189.

Ismail, A.; M.I. Abu-Doubara; F.A. Mansour and M.M. Zaky (2005). Isolation and identification of Yersinia species from water and fishes of Manzala Lake, Egypt. N. Egypt. J. Microbiol. 12: 147154.

Khalil, M.T. (1990). Physical and chemical environment of Lake Manzala, Egypt. Hydrobiologia . 196 (3): 193-199. Quinn, J.P.; M.B. Gillan and H. McGrogan (1985). The planktonic and benthic bacterial populations of Lough Neagh. J. Appl. Bacteriol. 58: 87-93.
Rhenheimer, G. (1980). Aquatic Microbiology. pp. 187-189. John Wiley \& Sons, New York, USA.

Ruhle, C.; C. Holler and K.O. Gundermann (1990). Quantitative and qualitative studies of Yersinia species in the waste water of purification plant. Zentralol. Hyg. Umwelt. Med. 189(4): 285-99.

Simpson, J.M.; J.W. Santo Domingo and D.J. Reasoner (2002). Microbial source tracking: state of the science. Environ. Sci. Technolo. 36(24): 5279-5288.

Soliman, Z.I. (1999). Antibiogram of some bacteria contaminating tilapia fish at El-Manzala Lake in port -Said governorate. Veterinary Medical J. Giza. 47(1): 19-27.

Trust, T.J. (1975). Bacteria associated with gills of Salmonid fishes in fresh water. Appl. Bacteriol. 38: 225-233.

Wahaab, R.A. and M.I. Badawy (2004). Water quality assessment of the River Nile system: an overview. Biomed. Environ. Sci., 17(1): 87-100.

World Health Organization, WHO (1989). Health Guidelines for the Use of Waste Water in Agriculture and Aquaculture. Vol. 2. Switzerland.

Zaky, M.M. (1995). Microbiological and Toxicological Study of The Environmental Pollution of Lake Manzala. pp 72-83. M.Sc. Thesis Suez Canal University, Ismailia, Egypt. 


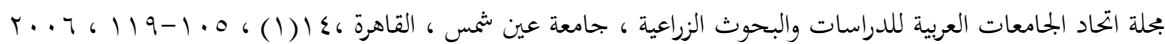

دراسات علي التلوث البكتيري في بحيرة المنزلة

[V]

فتحى عواد منصور ' - أحمد إسماعيل' - محمد إسماعيل أبو دبارة" -

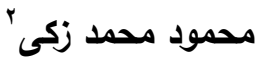

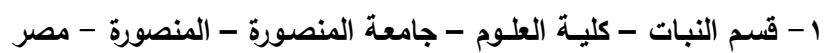

r- قسم العوم البيولوجية - كلية التربية - جامعة قناة السويس - بور سعيد - مصر النور

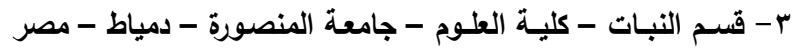

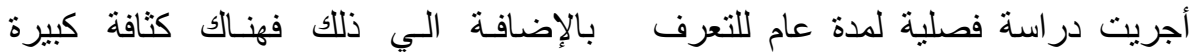

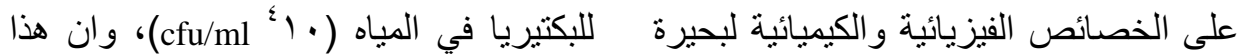

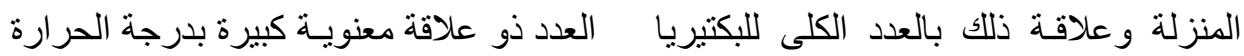

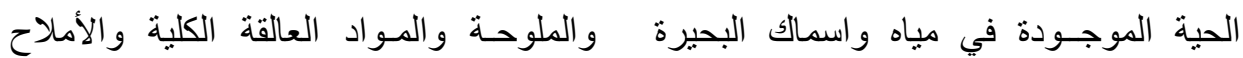

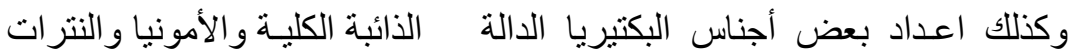

$(\mathrm{r}=0.92,0.98,0.94,0.97,0.68$ and 0.87 ;

$\mathrm{P}<0.05)$.

كما سجلت النتائج وجود دلائل التلوث

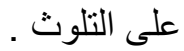

أظهرت النتائج ان خصائص المياه تتخير

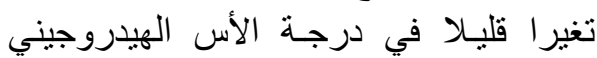

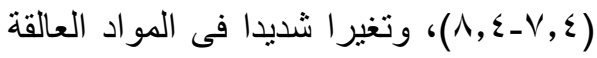

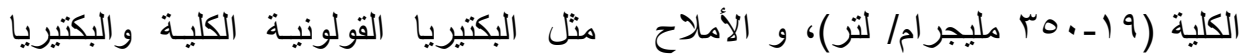

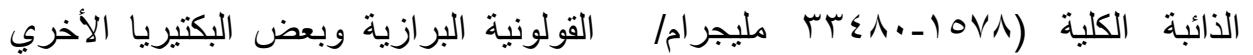

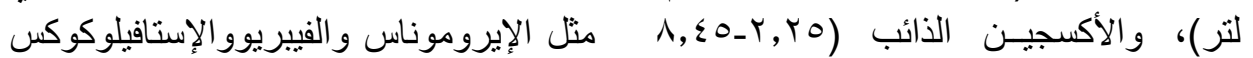

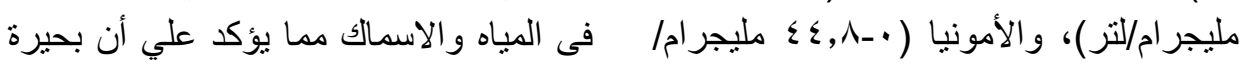

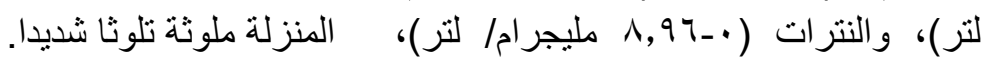

\footnotetext{
تحكيم: أ.د السيد أحمد صالح

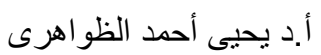

